\title{
PENGARUH HADIS DALAM ILMU FIQIH DAN TEOLOGI (Kajian Tokoh dan Pemikiran Imam Syafii)
}

\author{
Syaroji Sy \\ Sekolah Tinggi Agama Islam (STAI) al-Haudl Ketapang, \\ Kalimantan Barat
}

\begin{abstract}
Abstrak:
Umat Islam memang sepakat bahwa al-Qur'an menjadi sumber utama, akan tetapi di sana lebih menjelaskan tentang garis-garis besar. Sementara itu, rincian yang lebih mengerucut sedikit ditemukan. Untuk itu, munculah berbagai ulama tafsir guna menjelaskan hal-hal yang lebih mudah dipahami oleh umat. Selain itu, sumber hadis pun begitu, di sana banyak hadis-hadis yang masih perlu diteliti akan keabsahannya, dan hadis pun tidak lepas dari penafsiran ulama. Imam Syafii ialah salah satu empat madzhab di mana merupakan kiblat madzhab sebagian besar umat muslim di Indonesia. Di mana hadis-hadis sangat berpengaruh bagi beliau dalam menetapkan hukum-hukum syariat yang ditawarkan itu menjadi kajian yang membutuhkan analisis kritis berdasarkan pemikiran secara teologis. Melalui hadis-hadis yang sepaham dan sesuai interpretasi beliau, maka akan berpengaruh pada hasil dari hukum-hukum yang telah dirumuskan maupun ilmu fiqih yang dicetuskannya. Sehingga, produk syariat Imam Syafii lebih cenderung digunakan sebagian besar umat muslim bahkan di dunia.

Kata kunci: Imam Syafii, hadis, hukum syariat, ilmu fiqih, pemikiran.
\end{abstract}

\section{Abstrac:}

Moeslem are agree that The Qur'an is a prime resources, but there are more explain about in outline. And something is more details only few to find. So as to come some interpretationist of The Qur'an were explained something so more easy to understood moeslem. Be sides it, like that hadis there are hadis need researched to validity and hadid don't lost of interprtationist. Imam Syafi'i is the one of four madzhabs where is be madzhab oriented for those of Moeslem in Indonesia. Hadis is very influence him to make syariah laws that offered to be studied and needed critic analysis grounded on thought in a theologist. Pass through of hadis that agree in interpretation with him, so will influence to report of laws were 
Pengaruh hadis dalam ilmu fiqih dan teologi

(kajian tokoh dan pemikiran imam syafii)

defined or fiqih is sparkes. So Imam Syafi'i's product syariah is tended used for those of Moeslem in the word.

Keywords: Imam Syafii, through of hadis, syariah laws, defined or fiqih, critic analysis

\section{Prolog}

Sejak awal kaum muslimin, sepakat bahwa dalam segala perkara mereka harus berpegang pada kitab suci al-Qur'an. Sementara itu, al-Qur'an melengkapi secara garis besar dan tidak terdapat rincian yang menyeluruh. Untuk itu, perlu ada dukungan hadis dan beberapa pemikiran ulama seperti ijma' dan qiyās. Dalam sejarah perkembangan Islam, khususnya di bidang madzhab lebih dikenal dengan empat madzhab. Mereka adalah Imam Abu Hanifah, Ahmad bin Hambal, Imam Malik, dan Imam Syafii. Masing-masing imam menawarkan berbagai ilmu-ilmu di bidang fikih atau hukum-hukum syariat Islam.

Tawaran tentang hukum syariat imam-imam tersebut pastilah merujuk pada sumber utama al-Qur'an dan hadis. Memang, umat Islam sepakat bahwa al-Qur'an menjadi sumber utama, akan tetapi di sana lebih menjelaskan tentang garis-garis besar. Sementara itu, rincian yang lebih mengerucut sedikit ditemukan. Untuk itu, muncullah berbagai ulama tafsir guna menjelaskan hal-hal yang lebih mudah dipahami oleh umat. Selain itu, sumber hadis pun begitu, di sana banyak hadis-hadis yang masih perlu diteliti akan keabsahannya, dan hadis pun tidak lepas dari penafsiran ulama.

Berdasarkan empat madzhab tersebut, pada kesempatan kali ini fokus membincangkan, mengkaji berbagai corak pemikiran Imam Syafii. Tidak hanya itu, pandangan beliau tentang hadis yang mampu mempengaruhi produksi hukum-hukum syariat yang ditawarkan itu menjadi kajian yang membutuhkan analisis kritis. Melalui hadis-hadis yang sepaham dan sesuai interpretasi beliau, maka akan berpengaruh pada hasil dari hukum-hukum yang telah dirumuskan.

Imam Syafii merupakan kiblat madzhab sebagian besar umat muslim di Indonesia. Untuk itu, dalam pembahasan ini adalah Imam Syafii, meliputi biografi, corak pemikirannya, hingga seberapa jauh pengaruh hadis-hadis bagi beliau dalam menetapkan hukum-hukum ilmu fikih yang dicetuskannya. Sehingga, produk syariat Imam Syafii lebih cenderung digunakan sebagian besar umat muslim bahkan di dunia.

\section{Biografi Imam Syafii}

Imam Syafii adalah salah seorang ulama yang sangat masyhur. Setiap orang yang memperhatikannya akan tertarik untuk mengetahui lebih dalam 
Pengaruh hadis dalam ilmu fiqih dan teologi (kajian tokoh dan pemikiran imam syafii)

pribadi, perilaku, dan peninggalannya yang telah membuat orang yang memperhatikannya menghormati, memuliakan, dan mengaguminya. Nama lengkapnya adalah Muhammad bin Idris bin al-Abbās bin Uthmān bin Shāfi bin al-Sāib al-Quraishì. la lahir pada tahun $150 \mathrm{H} / 767 \mathrm{M}$ di Fustat (Kairo) Mesir. Ia sering juga dipanggil dengan nama Abū Abdullah, karena salah seorang putranya bernama Abdullah. Setelah menjadi ulama besar dan mempunyai banyak pengikut, ia lebih dikenal dengan nama Imam Syafii dan mazhabnya disebut mazhab Syafii.

Kata Shāfīi dinisbatkan kepada kakeknya yang ketiga, yaitu Shāfīi bin al-Sāib bin Abīd bin Abdul Yazìd bin Hashìm bin al-Mutalib bin Abdul Manāf. Sedangkan ibunya bernama Fătimah binti Abdullah bin alHasan bin Husain bin A $\bar{i}$ bin Abi Taălib. Dari garis keturunan ayahnya, Imam Syafii bersatu dengan keturunan Nabi Muhammad SAW pada Abdul Manaf, kakek Nabi SAW yang ketiga. Sedangkan dari pihak ibunya, ia adalah cicit dari Ali bin Abi Ṭālib. Dengan demikian, kedua orang tuanya berasal dari bangsawan Arab, Quraish. ${ }^{1}$

Kedua orang tua Syafii meninggalkan Makkah menuju Gaza (suatu tempat di Palestina) ketika masih dalam kandungan. Tidak beberapa lama setelah tiba di Gaza, ayahnya jatuh sakit dan meninggal dunia. Beberapa bulan sepeninggal ayahnya ia dilahirkan dalam keadaan yatim. Syafii diasuh dan dibesarkan oleh ibunya sendiri dalam kehidupan yang sangat sederhana, bahkan banyak menderita kesulitan. Setelah Syafii berumur dua tahun, ibunya membawanya pulang ke kampung asalnya Makkah, di sinilah Syafii tumbuh dan dibesarkan. ${ }^{2}$

Dari segi urutan masa, Imam Syafii merupakan imam ketiga dari empat orang imam yang masyhur. Tetapi, keluasan dan jauhnya jangkauan pemikirannya dalam menghadapi berbagai masalah yang berkaitan dengan ilmu dan hukum fikih menempatkannya menjadi pemersatu semua imam. Sehingga menampakkan dengan jelas pribadinya yang ilmiah. ${ }^{3}$ Bila kedua imam pendahulunya, yaitu Abu Hanifah dan Malik bin Anas masingmasing telah menjadi pemimpin pendekatan ahlu a l-ra'yi dan ahlu alhadith, maka Imam Syafii menggunakan kedua pendekatan itu dalam memahami kandungan al-Qur'an dan Sunnah. Sikap inilah yang membuat Syaikh Muhammad Abū Zahrah berpendapat bahwa Imam Syafii telah

\footnotetext{
${ }^{1}$ Dahlan Abdul Azis, Ensiklopedia Islam, Jilid 4, (Jakarta: Ichtiar Baru Van Hoeve, t.th.), hlm. 327.

${ }^{2}$ Ibid.

${ }^{3}$ Mustofa Muhammad Asy-Syakah, Islam Tidak Bermazhab, (Jakarta: Gema Insani Press, 1995), h1m. 349.
} 
Pengaruh hadis dalam ilmu fiqih dan teologi

(kajian tokoh dan pemikiran imam syafii)

menyatukan fiqh ahlu al-ra'yi dan fiqh ahlu al-hadith dengan kadar ukuran yang seimbang. ${ }^{4}$

Ahmad asy-Syurbasy berpendapat, Imam Syafii lebih dekat dengan pendekatan ahlu al-hadith, namun kemudian beralih kepada pendekatan ahlu al-rayi. Barangkali kedua pendapat tersebut menunjukkan betapa besar andil Imam Syafii dalam mengembangkan kedua pendekatan itu. Abū Zahrah menilai Imam Syafii telah menyatukan dan menempatkan secara setara kedua pendekatan itu, sementara Asy-Syurbasy berpendapat bahwa Imam Syafii telah menyatukan kedua pendekatan itu tetapi dengan menarjih salah satunya, atau condong kepada salah satu pendekatan itu.

Terlepas dari kesamaan atau perbedaan penilaian dalam hal itu; yang jelas pribadi Imam Syafii, ilmu, adab, agama dan tingkah lakunya menunjukkan model tersendiri yang amat langka dalam dunia ilmu dan ulama. Hal inilah yang antara lain yang melatarbelakangi Imam Ahmad bin Hanbal berpendapat, bahwa Imam Syafii adalah mujtahid abad kedua hijriyah. Menurut Imam Ahmad, Umar bin Abdul Azis adalah mujaddid kurun seratus tahun pertama, sedangkan pada kurun kedua, ia berharap mujaddid itu adalah Imam Syafii. ${ }^{5}$

Potensi keilmuan Imam Syafii telah menonjol sejak ia masih kecil. Kelebihan itu terus berkembang hingga ia wafat. Di mana wafat beliau setelah salat Maghrib hari Kamis malam Jumat, akhir dari bulan Rajab, tahun $204 \mathrm{H}$, tepatnya pada 28 Juni 819 M, di Mesir dalam usia 54 tahun. ${ }^{6}$ Imam Syafii sendiri pernah mengungkap masa kanak-kanaknya dengan kata-kata aku berada di tempat seorang alim yang rnengajarkan tulismenulis dan membaca al-Qur'an kepada murid-muridnya, kemudian aku menghafalnya. $^{7}$

Selain kehidupan Imam Syafii, terdapat latar belakang pendidikan dan guru ia. Pendidikan Imam Syafii dimulai dari belajar membaca alQur'an. Sejak usia dini ia telah memperlihatkan kecerdasan dan daya hafal Yang luar biasa. Dalam usia sembilan tahun, Imam Syafii sudah menghafal seluruh isi al-Qur'an, Imam Syafii berangkat ke dusun Baduwi, Banū Huzail, untuk mempelajari bahasa Arab yang asli dan fasih. Di sana, selama bertahun-tahun Imam Syafii mendalami bahasa, sastra, dan adat istiadat Arab yang asli. Berkat ketekunan dan kesungguhan Imam Syafii

\footnotetext{
${ }^{4}$ Ibid.

${ }^{5}$ Ibid., hlm. 350

${ }^{6}$ Suradjuddin Abbas, Sejarah dan Keagungan Madzhab Syafii, (Jakarta: Radar Jaya, 1995), hlm. 34.

${ }^{7}$ Ibid
} 
kemudian dikenal sangat ahli dalam bahasa Arab dan kekusastraan, mahir dalam membuat syair, serta mendalami adat istiadat Arab yang asli. ${ }^{8}$

Kemahiran Imam Syafii dalam bersyair mendapat pengakuan dari ahli-ahli syair, di antaranya Yūnus bin Abdul Alā. Dalam halaqah-halaqah yang ia bina, ia sering mengawalinya dengan membimbing para penuntut ilmu dengan masalah-masalah yang berkenaan dengan al-Qur'an dan diakhiri dengan halaqah yang membahas masalah syair. ${ }^{9}$

Setelah belajar di dusun Baduwi, Imam Syafii kembali ke Makkah dan belajar ilmu fikih pada Imam Muslim bin Khālid al-Zannī, seorang ulama besar dan mufti di kota Makkah, sampai memperoleh ijazah berhak mengajar dan memberi fatwa. Selain itu, Imam Syafii juga mempelajari berbagai cabang ilmu agama lainnya seperti ilmu hadits dan ilmu al-Qur'an. Untuk ilmu hadits, ia berguru pada ulama hadits terkenal di zaman itu, Imam Sufyan bin Uyainah, sedangkan untuk ilmu al-Qur'an kepada ulama besar Imam Ismaìl bin Qastantin.

Di samping seorang yang cerdas, Imam Syafii juga sangat tekun dan tidak kenal lelah dalam belajar. Pada usia sepuluh tahun, ia sudah membaca seluruh isi kitab al-Muwatta, karangan Imam Malik dan pada usia lima belas tahun telah menduduki kursi mufti di Makkah. Selain menuntut ilmu, Imam Syafii hidup serba kekurangan dan penuh penderitaan. Diriwayatkan karena kemiskinan dia hampir-hampir tidak bisa mempersiapkan peralatan belajar yang diperlukan sehingga dia terpaksa mencari-cari kertas yang tidak terpakai atau telah terbuang, akan tetapi masih dapat dipergunakan untuk menulis. ${ }^{10}$

Sekalipun Imam Syafii telah mempelajari dan menghafal kitab alMuwatta' susunan Imam Malik di bawah gurunya Sufyan bin Uyainah, tetapi ia belum puas jika tidak belajar di bawah penyusunnya sendiri, pada waktu itu berusia 21 tahun dengan surat pengantar dari guru Muslim bin Khālid dengan maksud berguru kepada Imam Malik, sekaligus memperdalam ilmu fikih yang amat diminatinya. Diceritakan bahwa dalam perjalanan antara Makkah dan Madinah yang ditempuh selama 8 hari Imam Syafii sempat menghatamkan al-Qur'an sebanyak 16 kali. Setibanya di Madinah, ia lalu shalat di Masjid Nabi SAW, baru kemudian menemui Imam Malik. Selama di Madinah, Imam Syafii tinggal di rumah gurunya, Imam Malik, ia sangat dikasihi oleh gurunya dan kepadanya diserahi tugas untuk mendiktekan isi kitab al-Muwatta' kepada murid-murid Imam Malik.

\footnotetext{
${ }^{8}$ Dahlan Abdul Azis, Ensiklopedia..., hlm. 327.

${ }^{9}$ Mustofa Muhammad Asy-Syakah, Islam..., hlm. 356.

${ }^{10}$ Departemen Agama RI., Pengantar Ilmu Fiqh, (J akarta: Proyek Pembinaan Perguruan Tinggi Agama, 1981), hlm. 89.
} 
Pengaruh hadis dalam ilmu fiqih dan teologi (kajian tokoh dan pemikiran imam syafii)

Berkaitan dengan kepribadian Imam Syafii, Muhammad Shattā alDimyați, dalam kitabnya I'anat al-Tālibīn Juz I menyebutkan sebagai berikut:

"Bahwasanya Imam Syafii membagi malam menjadi tiga bagian, sepertiga untuk belajar, sepertiga untuk shalat dan sepertiganya lagi untuk tidur dan beliau setiap harinya menghafalkan al Qur'an sekali sedangkan pada bulan Ramadhan beliau menghafalkan sampai 60 kali khataman yang kesemuanya itu beliau baca sewaktu dalam shalat."

Kepribadian tersebut sangat relevan untuk diaplikasikan bagi generasi muda saat ini, di mana kemajuan zaman dan teknologi mampu mempengaruhi pemikiran-pemikiran dan pola hidup mereka. Mencetak generasi Qurani memang perlu ditanamkan sejak dini, sehingga nilai-nilai Qurani itu diharapkan mampu mengkristal di jiwa umat muslim.

\section{Karya-karya Imam Syafii}

Imam Syafii menyusun banyak karya tulis yang berkaitan ilmu fikih dan ilmu hadits. Yaqūt al-Hanawi menyatakan bahwa Imam Syafii telah menyusun 147 buah karya tulis, tidak termasuk al-Risālah dan al-Um. Hanya saja kita tidak dapat mengatakan bahwa semua karya tulis Imam Syafii berbentuk kitab. Karya tulis itu misalnya, Salät al-Khusūus, Kariyyul Ibili wa al-Rawāhil, muzāra'ah, al-Musāqah, kitāb al-Razā, kitāb Khatabut Tabīb, Salāt al-Khaūf, Salāt al-Janāiz, dan Yamīn Maà al-Shahìd. Hanya risalah-risalah tipis. 19

Adapun kitab-kitab karangan Imam Syafii Menurut riwayat yang hingga sekarang ini masih tercatat adalah sebagai berikut.

1. Kitab al-Risālah, kitab ini disusun berkaitan dengan kaedah usul fikih yang di dalamnya, diterangkan mengenai pokokpokok pegangan Imam Syafii di dalam meng-istinbat-kan hukum atau kitab ini berisi khusus tentang usul fikih.

2. Kitab al-Um, kitab ini adalah satu-satunya kitab fikih yang disusun oleh Imam Syafii dan kitab ini adalah kitab fikih yang penjelasannya tidak ada bandingannya pada masa sekarang ini, di dalam kitab ini terdapat pula kitab-kitab sebagai berikut:

a) Kitab Jāmi' al-Ilmi, yang berisi tentang pembelaan Imam Syafii mengenai sunnah Nabi.

b) Kitab Ibtāl al-Istihsān, kitab ini berisi tentang tanggapan Imam Syafii kepada para ulama Irāq

\footnotetext{
${ }^{11}$ Muhammad Shattā al-Dimyātī, Ianat al-Ṭālibīn, Juz I, (Mesir: Musțafā al-Halabī, 1942), hlm. 16.
} 
Pengaruh hadis dalam ilmu fiqih dan teologi

(kajian tokoh dan pemikiran imam syafii)

(Baghdad) yang sebagian dari mereka suka mengambil hukum dengan cara istihsān.

3. Kitab al-Raddu 'alā Muhammad bin Hasan, yaitu kitab yang berisi tentang pertahanan imam Syafii terhadap Imam Muhammad ibnu Hasan kepada ulama ahli Madinah.

4. Kitab Siräj al-Hadith, yaitu kitab yang berisi mengenai pembelaan Imam Syafii terhadap Imam al-Auzai.

5. Kitab Ikhtiläf al-Hadith, yaitu kitab yang berisi di dalamnya mengungkapkan perbedaan-perbedaan ulama dalam persepsi tentang hadits mulai dari sanad sampai kepada rawi yang dapat dipegangi, termasuk analisis beliau tentang hadits yang menuntutnya supaya dapat dijadikan sebagai pegangan hujjah.

6. Kitab al-Musnad, kitab ini berisi sandaran (sanad) Imam Syafii dalam meriwayatkan hadits Nabi yang beliau himpun dalam kitab al-Um. ${ }^{12}$

\section{Corak Pemikirannya}

Dalam meng-istinbat-kan (mengambil dan menetapkan) suatu hukum. Imam Syafii dalam bukunya al-Risālah menjelaskan bahwa ia memakai lima dasar, yaitu al-Qur'an, Sunnah, Ijma, Qiyās, dan istidlāl (penalaran). Kelima dasar inilah yang kemudian dikenal sebagai dasar-dasar mazhab Imam Syafii. Dasar pertama dan utama dalam menetapkan hukum adalah al-Qur'an. Imam Syafii terlebih dahulu melihat makna lafzi $\bar{i}$ (perkataan) al-Qur'an. Kalau suatu masalah tidak menghendaki makna lafżi barulah ia mengambil makna majāzi (kiasan). Kalau di dalam al-Qur'an tidak ditemukan hukumnya, ia beralih kepada sunnah Nabi SAW. Dalam hal sunnah, ia juga memakai hadith ahad (perawinya satu orang) di samping yang mutawätir (perawinya banyak orang), selama syarat-syarat hadits ahad itu mencukupi. Jika di dalam sunnah pun belum dijumpai nas-nya, ia mengambil ijma' sahabat. Setelah mencari dan tidak ditemukan ketentuan hukumnya barulah ia melakukan qiyās. Jika ia tidak menjumpai dalil dari ijma' dan qiyās, ia memilih jalan istidlāl, yaitu menetapkan hukum berdasarkan kaidah-kaidah umum agama Islam. ${ }^{13}$

Fiqh Shäfiì. Fikih merupakan campuran antara Fiqh Ahlu al-Ra'yi dengan Fiqh Ahlu al-Hadith. Kedua metode tersebut memiliki cara

\footnotetext{
12 Munawar Khalil, Biografi Empat Serangkai Imam Mazhab, (Jakarta: Bulan Bintang, 1954), hlm. 241-243.

${ }^{13}$ Muhammad bin ldris Al-Shāfīi, al-Risalah, (Beirūt Libanon: Dār al-Fikr, t.th.), hlm.512. Lihat juga Imam Shāfii, Al-Risālah, Ahmadie Thoha (terj.), (Jakarta: Pustaka Firdaus, 1986), hlm. 125 dan 181
} 
Pengaruh hadis dalam ilmu fiqih dan teologi

(kajian tokoh dan pemikiran imam syafii)

tersendiri dalam ber-istinbat. Ahlu al-Ra'yi adalah para cendekiawan yang memiliki pandangan luas, tetapi kemampuan mereka untuk menerima athar dan sunnah-sunnah sangat terbatas. Sementara itu, Ahlu a 1 - Hadith sangat gigih mengumpulkan hadits, athar dan beberapa hal lainnya yang berkaitan dengan perbuatan para sahabat. Namun mereka bukan ahli munāqasah dan istinbat. Jadi, ahli fikih hendaknya mampu menggunakan ra'yi dan sekaligus hadith. Imam Syafii adalah seorang ahli dalam kedua metode itu. Kecerdasannya yang sangat tinggi menjadikannva seorang yang sangat mahir dalam rayi dan munāqasah. ${ }^{14}$ Pada saat yang sama ia juga seorang ulama daiam ilmu hadits yang mampu membangkitkan para ahli hadits lainnya. Sehingga oleh para ulama pada zamannya ia dijuluki penolong sunnah. Lebih dari itu, ia tidak sekadar ahli dalam kedua pendekatan itu, tetapi juga mampu untuk menyatukan keduanya dan membangun fikih di atasnya serta mencetuskan ilmu ushul fikih yang merupakan salah satu unsur pokok dalam mazhabnya.

1. Dalam pandangan Imam Syafii, pendekatan ahli hadith lebih jelas dalam masalah usul. Karenanya, ia menggunakan al-Qur'an sebagai sumber hukum dan pokok-pokok syariat. Setelah itu la merujuk pada hadits. Jika dengan penggunaan hadits telah dianggap cukup dalam menetapkan hukum, maka ia tidak menggunakan ra'yi. Prinsip yang digunakan adalah seperti yang diucapkannya, apapun pendapat yang telah aku kemukakan, bila kemudian ternyata ada yang berlawanan denga pendapat itu, maka pernyataan Rasulullah saw. itu pendapatku. ${ }^{15}$

2. Imam Syafii menolak penggunaan kaidah istihsān, sebagaimana dinyatakan dalam kitab Ibtăl al-Istihsān. Metode ini adalah metode yang biasa digunakan Abu Hanifah. Menurut Imam Syafii, dalam penerapan metode ini seorang ahli fikih setelah merujuk kepada alQur'an, sunnah, ijma', qiyās, ia menetapkan hukum yang dipandangnya baik, dan bukan hanya berpegang kepada dalil alQur'an dan sunnah. Imam Syafii menyatakan, bila ijtihad ditetapkan dengan menggunakan metode istihsān tanpa sepenuhnya bersandar kepada pokok syariat atau nas al-Qur'an dan sunnah, maka ijtihād tersebut batil. ${ }^{16}$

Di literatur lain dijelaskan bahwa para fuqahă' belum memiliki kesepakatan tentang batas dan syarat syaratnya ijma' itu, apakah ijma' itu hanya kaum muslimin secara menyeluruh, apakah ijma' harus mencakup

\footnotetext{
14 Ibid., hlm. 513.

${ }^{15}$ Mustfāa Muhammad al-Shakah, Islam..., hlm. 359.

${ }^{16}$ Dahlan Abdul Azis, Ensiklopedia..., hlm. 329.
} 
Pengaruh hadis dalam ilmu fiqih dan teologi (kajian tokoh dan pemikiran imam syafii)

keseluruhan pendapat para ulama ataukah pendapat mayoritas mereka saja. Dalam kitabnya al-Um imam Syafii telah menolak teori Imam Malik mengenai kunsesus ulama lokal atau sedaerah saja (al-ijma' al-mahalli atau al-iq(imī). Beliau memberikan penjelasan bahwa yang beliau maksudkan adalah kesepakatan pendapat pada setiap masa, dan selalu dipengaruhi oleh ulama setiap generasi, agar masyarakat berkembang sesuai dengan perkembangan zaman.

Selain itu dalam fikih Imam Syafii apabila seorang mujtahid tidak menemukan ketentuan hukum dalam nas al-Qur'an dan hadits, maka dia harus mencarinya dengan jalan memeriksa, meneliti dan mencari "illat atau sebab" hukum yang terdapat di dalam nas al-Qur'an dan Hadits. Kemudian jika illat suatu ketetapan hukum itu serupa atau mirip dengan illat suatu kasus yang baru, maka illat yang terdapat didalam nas dapat dijadikan dasar untuk menetapkan ketentuan hukum yang baru, inilah yang disebut dengan Qiyās. Dengan metode qiyās inilah Imam Syafii berhasil meredakan silang pendapat antara kaum Ahlu al-Ra'yi dan kaum Ahlu al-Hadith. dari penjelasan di atas jelaslah bahwa dalam fiqih Imam Syafii Ijma' dulu baru Qiyās.

Selain menggunakan al-Qur'an, Hadits, Ijma', Qiyās Imam Syafii juga memakai istidlāl, semua itu apabila beliau dalam suatu urusan yang bertalian dengan hukum sudah tidak mendapati dalil dari ijma' dan tidak ada jalan dari qiyās, maka barulah beliau mengambil dengan jalan istidlāl, mencari alasan, bersandarkan atas qaidah-qaidah agama meskipun dari agama ahli kitab, beliau tidak mau mengambil hukum dengan cara istihsān seperti yang biasa dikerjakan oleh para ulama dari pengikut Abu Hanifah di Baghdad dan lain-lain. ${ }^{17}$

\section{Sunnah dalam Pandangan Imam Syafii}

Imam Syafii memberikan batasan alasan atau argumen kepada ahlu al'ilmi mengenai khabar yang khusus atau istimewa, yaitu khabar yang diterima dari seorang rāwi kepada rāwi yang lainnya yang sanadnya sampai pada Rasulullah SAW.

Argumen itu sendiri tidak akan terwujud atau terlaksana kecuali dengan alasan khusus, hingga mencakup beberapa hal, antara lain:

1. Agar yang menyampaikan orang yang kuat agamanya, jujur dalam tutur katanya, sadar apa yang ia katakan, mengetahui secara leterlek dalam memahami makna hadits dari lafalnya.

17 Fauzinesia, "Sejarah Kehidupan dan Pemikiran Imam Syafii", dalam fauzinesia.blogspot.com, posted 18 Juni 2012 
Pengaruh hadis dalam ilmu fiqih dan teologi

(kajian tokoh dan pemikiran imam syafii)

2. Menyampaikan hadits secara harfiah dari apa yang ia dengar dengan tidak menyampaikan secara makna, karena jika disampaikan dengan makna maka tidak akan diketahui alasan dari maknanya. Dan tidak akan diketahui apakah yang halal berubah menjadi haram.

Kriteria hadits menurut Imam Syafii:

1. Asas dasar dengan sendirinya, dan tidak di-qiyās-kan pada yang lain karena qiyās itu lebih lemah dari dasar.

2. Menjadikan hadits sebagai kesaksian yang diketahui secara umum.

Terkadang kesaksian-kesaksian itu mengalami perbedaan dan persamaan dalam beberapa hal. Dikatakan berbeda atau bertentangan apabila hadits yang rawinya seorang pria atau wanita dan tidak diterimanya salah satu dari keduanya dalam kesaksian. Hadits: "Fulān telah meriwayatkan hadits padaku dari Fulānah". Hadits ini dapat diterima apabila perawi bukan penipu, dan kesaksiannya hanya diterima jika terdapat kata, sami 'tu, Raaitu, atau Ashhadani. ${ }^{18}$

Imam Syafii mendiskusikan dan menjelaskan kelemahan hadits dan menguraikan bahwa adanya pertentangan-pertentangan hadits dikarenakan banyak faktor. Suatu kontradiksi mungkin timbul disebabkan suatu hadits sudah di-nasakh oleh hadits yang lain atau karena adanya kesalahan yang dilakukan dalam periwayatannya. Kesalahan-kesalahan yang demikian mungkin menyebabkan adanya pertentangan yang dimaksud, dan masih banyak faktor lagi. risalah:

Teori Imam Syafii tentang hadits paling baik dipahami melalui teks

'Setiap hadits yang diriwayatkan oleh seorang perawi yang dapat dipercaya yang bersumber pada Nabi, adalah otoritatif dan dapat ditolak hanya jika ada hadits otoritatif lain dari Nabi yang menentangnya. Jika peraturan terdahulu dicabut oleh peraturan yang datang kemudian, maka yang datang kemudian diterima, jika tidak ada informasi yang diketahui tentang pencabutan, maka dua hadits lebih dapat dipercaya itulah yang diikuti. Jika keduanya sama-sama dapat dipercaya, maka yang lebih sesuai dengan al-Qur'an dan Sunnah Nabi-lah yang dipilih. Hadits-hadits dari orang lain tidak dapat diperhitungkan jika berhadapan dengan hadits Nabi, baik hadits itu mendukung atau bertentangan dengannya. Jika orang-orang itu

18 Muhammad Taisir, "Pandangan Imam Syafii tentang Sunnah", dalam link24shake.blogspot.com/2012/11/pandangan-imam-Syafii-tentang-sunnah_9862.html, posted November 2012. 
Pengaruh hadis dalam ilmu fiqih dan teologi

(kajian tokoh dan pemikiran imam syafii)

bersikap hati-hati terhadap hadits dari Nabi maka mereka mesti mengikutinya". ${ }^{19}$

Keteguhannya memegang hadits Nabi termanifestasikan dalam sikapnya yang menganggap semua hadits sama-sama mengikat dan jika dipertimbangkan maka ia menggunakan interpretasi yang mengharmoniskan dan ia tidak pernah menganggap dua hadits yang bertentangan jika ada cara untuk menerima keduanya. Jika kedua hadits tidak bisa dikompromikan maka ia akan memilih yang lebih sesuai dengan al-Qur'an dan mempertahankan bagian dari sunnah Nabi yang tidak dipersoalkan lagi. ${ }^{20}$

Al-Qur'an baginya merupakan dasar pengetahuan hukum dan penjelasan tentang segala sesuatu, spiritual dan temporal di mana orang beriman diharuskan mengamatinya. Ia membagi hukum al-Qur'an ke dalam kategori yang berbeda. "Ada, ia mengamati peraturan umum yang dapat dijelaskan dengan konteks, akan tetapi juga ada aturan implisit". Ia menambahkan, ada peraturan umum dimana hanya sunnah yang dapat menentukan umum atau khusus. ${ }^{21}$ Konsepnya ini dianggap sebagai unsur yang sangat penting dalam penafsiran ayat-ayat al-Qur'an.

Ia membatasi penggunaan qiyās atau analogi untuk masalah-masalah detail. Pada prinsipnya, Syafii mengakui hanya penalaran sistematis analogis yang ketat untuk mengeluarkan pendapat yang berubah-ubah dan keputusan yang bebas.

Mengenai masalah yang tidak ada dalam al-Qur'an, Sunnah Nabi maupun ijma, maka hukum dapat disimpulkan dengan menggunakan analogi, dari apa yang telah diletakkan oleh otoritas-otoritas ini.

Jadi Syafii memperbolehkan penalaran hanya melalui qiyās atau analogi. Dalam ia menggunakan analoginya, ada perbedaan pemahaman sementara mencoba untuk menentukan paralelisme antara kasus yang ada dengan peraturan dalam al-Qur'an atau Sunnah, yang sama dalam beberapa hal tetapi tidak paralel, para pendahulunya bertumpu pada penalaran pribadi, tetapi ia tidak mau menerima alasan tersebut tanpa petunjuk tertentu yang jelas, dalam konteks yang menunjukkannya. Oleh karena itu pemikiran harus analogis dan tidak individual. ${ }^{22}$

Adapun jelasnya tentang ini cukup kita mengikuti mengutip perkataan-perkataan ulama madzhab, salah satunya yaitu:

\footnotetext{
${ }^{19}$ Ibid.

${ }^{20}$ QS. Ali Imrān: 103.

${ }^{21}$ Muhammad Khoidduri, Islamic Jurisprudence, (Baltimore: Syafiis Risalah, 1961), hlm. 35.

22 Muhammad Muslehuddin, Filsafat Hukum Islam dan Pemikiran Orientalis: Studi Perbandingan Sistem Hukum Islam, Yudian Wahyudi (terj.), (Yogyakarta: PT. Tiara Wacana, 1997), hlm. 32.
} 
Pengaruh hadis dalam ilmu fiqih dan teologi

(kajian tokoh dan pemikiran imam syafii)

"Imam Ahmad ibnu Hanbal mengatakan: "saya pernah bertanya kepada Imam Syafii mengenai qiyās (analogi), maka beliau menjawab: di kala keadaaan darurat".

Yakni, Imam Syafii menentukan hukum secara qiyās apabila keadaan memaksa, tidak ada nasakh dari al-Qur'an dan Sunnah. Maka jika masih terdapat nasakh al-Qur'an dan atau keterangan dari Sunnah Nabi, niscaya beliau tidak akan menetapkan hukum secara qiyās (analogi).

\section{Epilog}

Berdasarkan penjelasan di atas menunjukkan bahwa Syafii sebagai pelopor hukum Islam yang menjadikan al-Qur'an merupakan dasar pengetahuan hukum dan penjelasan tentang segala sesuatu, spiritual dan temporal di mana orang beriman diharuskan mengamatinya. Dalam hal ini Syafii secara tidak langsung mengakui adanya peranan ilmu berasal dari Tuhan dan hadits-hadits Nabi saw. berfungsi menjelaskan al-Qur'an. Oleh karena itu al-Qur'an harus ditafsirkan dengan sinaran hadits, bahkan juga melengkapinya, bukan malah sebaliknya.

Selain al-Qur'an dan hadis, imam Syafii juga merujuk sumber ijma', qiyās, dan istidlāl. Kelima dasar inilah yang kemudian dikenal sebagai dasardasar mazhab Imam Syafii. Dalam merumuskan, beliau memperhatikan urutan-urutan yang sistematis. Sumber awal yakni mulai dari al-Qur'an, ketika di sana tidak ada maka jalur hadis. Dalam ajaran Syafii adalah membatasi penggunaan bebas pendapat pribadi dan menekankan otoritas hadits Nabi sebagai penentu hukum. Terdapat pada hadits-hadits inilah penekanan terhadap sunnah Nabi dalam menentukan suatu hukum. Konsep ini dianggap sebagai unsur yang sangat penting dalam penafsiran ayat-ayat al-Qur'an. Hadits Ahad yang diriwayatkan oleh seorang perawi yang dapat dipercaya yang bersumber pada Nabi, adalah otoritatif dan dapat ditolak jika ada hadits lain dari Nabi yang menentangnya. Selanjutnya, jika dari hadis belum menemukan nas-nya, maka melangkah pada tahap ijma' sahabat. Setelah mencari dan tidak ditemukan ketentuan hukumnya barulah ia melakukan qiyās. Sedangkan mengenai penerimaan qiyās itu berlaku apabila ia berfungsi memperluas arti dari pada al-Qur'an dan Sunnah. Dan qiyās yang benarlah yang dianggap dan diambil oleh Syafii. Jika ia tidak menjumpai dalil dari ijma' dan qiyās, ia memilih jalan istidlāl, yaitu menetapkan hukum berdasarkan kaidah-kaidah umum agama Islam.

\section{Daftar Pustaka}

Abbas, Suradjuddin. Sejarah dan Keagungan Madzhab Syafii, Jakarta: Radar Jaya, 1995. 
Pengaruh hadis dalam ilmu fiqih dan teologi (kajian tokoh dan pemikiran imam syafii)

Azis, Dahlan Abdul. Ensiklopedia Islam, Jilid 4, Jakarta: Ichtiar Baru Van Hoeve, t.th.p[

Agama, Departemen RI. Pengantar Ilmu Fiqh, Jakarta: Proyek Pembinaan Perguruan Tinggi Agama, 1981.

al-Dimyatì, Muhammad Shattā, Iānāt al-Ṭālibīn, Juz I, Mesir: Musțafā alHalabì, 1942.

Fauzinesia, "Sejarah Kehidupan dan Pemikiran Imam Syafii", dalam fauzinesia.blogspot.com, posted 18 Juni 2012.

Khalil, Munawar, Biografi Empat Serangkai Imam Mazhab, Jakarta: Bulan Bintang, 1954.

Khoidduri, Muhammad, Islamic Jurisprudence, Baltimore: Syafiis Risalah, 1961.

Muhammad Taisir, "Pandangan Imam Syafii tentang Sunnah", dalam link24shake.blogspot.com/2012/11/pandangan-imam-Syafii-tentangsunnah_9862.html, posted November 2012.

Muslehuddin, Muhammad, Filsafat Hukum Islam dan Pemikiran Orientalis: Studi Perbandingan Sistem Hukum Islam, Yudian Wahyudi (terj.), Yogyakarta: PT. Tiara Wacana, 1997.

Al-Shāfiì, Muhammad bin ldrīs, al-Risālah, Beirut Libanon: Dār al-Fikr, t.th. Lihat juga Imam Syafii, Ar-Risalah, Ahmadie Thoha (terj.), Jakarta: Pustaka Firdaus, 1986.

Asy-Syakah, Mustofa Muhammad, Islam Tidak Bermazhab, Jakarta: Gema Insani Press, 1995. 